IRSH 5I (2006), pp. 243-276 DOI: I0.1017/S0020859006002446

(C) 2006 Internationaal Instituut voor Sociale Geschiedenis

\title{
Unfree Labor, Apprenticeship and the Rise of the Victorian Hull Fishing Industry: An Example of the Importance of Law and the Local State in British Economic Change*
}

\author{
MARC W. STEINBERG
}

Summary: Within the last decade there has been considerable renewed attention on the importance of British master and servant law in the eighteenth and nineteenth centuries as a means of labor discipline and control. This article argues for further analyses of how the law was used within local contexts and specific industries and calls for increased focus on the role of the local state in labor relations. It argues that unfree labor played an important role in the development of some industries, and challenges claims of the demise of apprenticeship in later nineteenth-century England. Through an analysis of the Hull fish trawling industry in I864-i875 it demonstrates that the exploitation of apprentice labor, and the control of fishing apprentices through punitive master-servant prosecutions were vital to the expansion of the trade.

On May i2, is66 Charles Taylor stood before Hull's stipendiary magistrate, Thomas Travis, charged by his master, a fishing-trawler owner, with being a disorderly apprentice. The case, as I will show in this paper, was a common one: Taylor, the apprentice, claimed abuse by his master and complained of his status as an unwaged worker. Since this was Taylor's first offence Travis was willing to order his return to work, rather than imposing a standard prison sentence, and warned his master against further physical abuse. However, Taylor "stoutly refused". He was no mere boy, but was twenty years old, and added an additional wrinkle:

Prisoner: I would sooner suffer imprisonment ten times over than go to sea without anything for my wife.

* Support for this research has been generously provided by the American Council for Learned Societies and Smith College. Previous versions of this paper have been presented at the annual meetings of the Social Science History Association in 2003 and the American Sociological Association in 2004. My thanks to James Jaffe, Anne Knowles, Robb Robinson, David Starkey, Robert Steinfeld, Laura Tabili, Charles Tilly, Martin Wilcox and the anonymous reviewers for the IRSH for their comments and suggestions. In addition, I am greatly indebted to Martin Taylor and the staff at the Hull City Archives for their insights and hard work on my behalf. 
Mr. Travis said the prisoner knew when he married that he had no wages.

Prisoner answered that he had no need for any wages for his wife so long as his father lived, but he was now dead. It was because of the child that he got married. Mr. Travis: You had a child, and then you married.

Prisoner: Yes, sir.

Mr. Travis: In that I think you did very right. Now just bethink you; go to sea like a good lad.

Prisoner said he couldn't do it. England was a free country, and he would not be treated like a slave.

Mr. Travis remarked to the master that he thought he would do wisely if he made the prisoner an advance wherewith to keep his wife.

Prosecutor said he would do that if the lad would do his work properly.

Mr. Travis, after observing that the prosecutor had no business to strike the lad, and that if he did so again he might expect to have the blow returned, said to the prisoner that he was a very obstinate fellow, and he must go to prison for forty days. ${ }^{\mathrm{I}}$

Taylor, by virtue of his apprenticeship, was legally unfree, which compounded his dilemma with the power of the court. Yet variations of Taylor's case were repeated hundreds of times in Hull in the midVictorian period for workers under regular conditions of service. Indeed, despite his polemical retort that England was a free country, tens of thousands of workers during this period were similarly caught in the web of the criminal justice system for disobeying the dictates of their employers. What is striking is that this particular form of exploitation, a regular occurrence in a number of regions in England during the Industrial Revolution, has received so little attention.

\section{LAW, APPRENTICESHIP AND THE LOCAL STATE}

The ways in which the English legal system was integral to labor exploitation in the nineteenth century was highlighted by a now classic essay by Daphne Simon in I954 on master and servant law, the precursor to modern employment law. ${ }^{2}$ Simon explored how this aspect of labor law was used, particularly in the first half of the century, as a strategy for labor discipline. Simon claimed that by the mid-Victorian period its use was on the wane, a relic of older forms of labor organization largely supplanted by industrial development.

While Simon's essay established an important agenda for research on the role of legal systems in general and the courts in particular in nineteenthcentury economic development and change, this path was largely 
neglected the next four decades. ${ }^{3}$ A review of contemporary surveys of the British industrial revolution and nineteenth-century economic development shows at best cursory attention to these issues. ${ }^{4}$ Indeed, in his recent survey of the role of government in the Victorian and Edwardian era economy Roger Middleton observes:

It is generally agreed that in no other advanced industrial economy has the law played a less significant role in shaping industrial relations than in Britain (Clegg I970: 343); it was voluntary dealings between capital and labour, variously organised, that determined the form and pace of developments. This voluntarist tradition dictated a non-interventionist stance by successive governments and suggests that, so far as economic performance is concerned, it is what governments did not do rather than what they did do that may be critical.s

Over the past decade or so, however, historians such as John Saville have called for further work in the area, and new research on the role of employment law and the state more generally on economic development and change has revitalized attention on these issues. ${ }^{6}$ Extensive work by Douglas Hay, Robert Steinfeld, Christopher Franks, Mark Curthoys and Wilibald Steinmetz has offered the foundations for a revised history of labor law in England in the eighteenth and nineteenth centuries. ${ }^{7}$ The

3. The exceptions are work on the Black Country, which had high rates of prosecution under master and servant laws. See David Philips, “The Black Country Magistracy i 835-60", Midland History, 3 (1976), pp. I6I-I90; D.C. Woods, "The Operation of the Master and Servants Act in the Black Country, I858-i875", Midland History, 7 (1982), pp. 93-i I.

4. Eric J. Evans, The Forging of the Modern State: Early Industrial Britain, $1783-1870$ (London, 1996, 2nd edn); Pat Hudson, The Industrial Revolution (London, 1992); Charles More, Understanding the Industrial Revolution (London, 2000); Neville Kirk, Change, Continuity and Class: Labour in British Society, 1850-1920 (Aldershot, 1994); Kenneth Morgan, The Birth of Industrial Britain: Social Change, 1750-1850 (Harlow: 2004). Richard Price, British Society, I660-I880: Dynamism, Containment and Change (Cambridge, I999) offers some important, more general considerations on the role of the state which I discuss below, but does not address the legal system more particularly. In his recent survey of the literature Joel Mokyr ignores the issue; see Joel Mokyr, "Accounting for the Industrial Revolution", in Roderick Floud and Paul Johnson (eds), The Cambridge Economic History of Modern Britain. Volume I: Industrialisation, $1700-1860$ (Cambridge, 2004), pp. I-27.

5. Roger Middleton, "Government and the Economy, 1860-1939", in Floud and Johnson, The Cambridge Economic History of Modern Britain, vol. 2: Economic Maturity, I860-1939, p. 486. 6. John Saville, "The Crisis in Labour History: A Further Comment", Labour History Review, 6I (1996), p. 326; idem, The Consolidation of the Capitalist State (London, 1994), pp. 22-23.

7. Douglas Hay and Paul Craven (eds), Masters, Servants, and Magistrates in Britain and the Empire, 1562-1955 (Chapel Hill, NC, 2004); Douglas Hay, "Patronage, Paternalism, and Welfare: Masters, Workers, and Magistrates in Eighteenth-Century England", International Labor and Working-Class History, 53 (1988), pp. 27-48; idem, "Master and Servant in England: Using the Law in the Eighteenth and Nineteenth Centuries", in Willibald Steinmetz (ed.), Private Law and Social Inequality in the Industrial Age: Comparing Legal Cultures in Britain, France, Germany and the United States (Oxford, 2000), pp. 227-264; Robert Steinfeld, Coercion, Contract, and Free Labor in the Nineteenth Century (Cambridge, 200I); Willibald Steinmetz, "Was there a De-juridification of Individual Employment Relations in Britain?", in idem (ed.), 
detailed analyses by these authors illuminate the ways in which master and servant law (to which I return below) legally tethered workers to capitalists for most of these two centuries. Charting the lineage of the Master and Servant Act of I 823, this history reveals that legally unfree labor was at least as much of a product of capitalist demands on the state originating in mid-eighteenth century, as it was a vestige of a feudal past.

More generally there has been renewed attention to the role of state in nineteenth-century economic transformation. As Ron Harris suggests in a recent survey of state activities,

The state seems to have surfaced almost everywhere in the economy. It not only regulated markets but also created them. It not only protected property rights but also defined them. It did not either own enterprises or leave them to be owned by private individuals, but was also a partner in joint public-private undertakings, be they new modes of transportation or new imperial conquests. It seems more appropriate to speak now of the state within the economy rather than of the state and the economy. ${ }^{8}$

A good deal of work on the role of the state in labor policy has focused on factory reform, working conditions (especially with regards to women), and the legal status of trade unions. ${ }^{9}$ Despite this increased focus on the

Private Law and Social Inequality in the Industrial Age: Comparing Legal Cultures in Britain, France, Germany and the United States (Oxford, 2000), pp. 265-312; Mark Curthoys, Governments, Labour, and the Law in Mid-Victorian Britain: The Trade Union Legislation of the I870s (Oxford, 2004); Christopher Franks, "He Might Almost As Well Be Without Trial': Trade Unions and the I823 Master and Servant Act - the Warrington Cases, 1846-47", Historical Studies in Industrial Relations, I 4 (Autumn 2003), pp. 343; idem, "The Defeat of the I 844 Masters and Servants Bill”, in Hay and Craven, Masters, Servants, and Magistrates in Britain and the Empire, pp. 402-42 I; Christopher Franks, "Let But One of Them Come Before Me, and I'll Commit Him': Trade Unions, Magistrates, and the Law in Mid-NineteenthCentury Staffordshire”, Journal of British Studies, 44 (2005), pp. 64-91. See also Simon Deakin, "The Contract of Employment: A Study in Legal Evolution", Historical Studies in Industrial Relations, I I (200I), pp. I-36. For the use of other criminal law for purposes of labor control during the Victorian era, see Barry Godfrey, "Law, Factory Discipline and 'Theft': The Impact of the Factory on Workplace Appropriation in Mid to Late Nineteenth-Century Yorkshire", British Journal of Criminology, 39 (1999), pp. 56-71, and idem, "Judicial Impartiality and the Use of Criminal Law Against Labour: the Sentencing of Workplace Appropriators in Northern England, I840-1880", Crime, History E Societies, 3 (1999), pp. 57-72.

8. Ron Harris, "Government and the Economy, I688-1850", pp. 204-237, in Floud and Johnson, The Cambridge Economic History of Modern Britain, vol. I: Industrialisation, I700I860, p. 235 .

9. Robert Gray, The Factory Question and Industrial England, I830-I860 (Cambridge, I996); Robert Gray and Donna Loftus, "Industrial Regulation, Urban Space and the Boundaries of the Workplace: Mid-Victorian Nottingham”, Urban History, 26 (1999), pp. 2 I I-229; Carolyn Malone, "Gendered Discourses and the Making of Protective Labor Leglisation in England, I830-I914", Journal of British Studies, 37 (1998), pp. I66-191; Sonya O. Rose, Limited Livelihoods: Gender and Class in Nineteenth-Century England (Berkeley, CA, I992); idem, "'From Behind the Women's Petticoats': The English Factory Act of I874 as a Cultural Production”, Journal of Historical Sociology, 4 (1991), pp. 32-51; Peter W.J. Bartrip, The Home 
state two lacunae remain. First, much of this research focuses as much or more on battles over legislation rather than on the actual enforcement of laws and their effects on industrial discipline and workplace relations. ${ }^{10}$ Yet, as Richard Price has cogently observed, "The British state was the law, and how the law was applied determined in particular cases whether the state was strong or weak." II

Second, and relatedly, the state in mid-Victorian Britain was, in Anne Digby's term, the "local state". ${ }^{12}$ For most working people the state was manifest in the local authorities that upheld the law, and the face of authority was very often that of the magistracy. Over the course of the nineteenth century magistrates' courts were given greater scope of authority and heightened powers of summary jurisdiction. ${ }^{\mathrm{I}}{ }^{3}$ In terms of statutory laws on employment and combination and common law assumptions concerning contract, and in the case of trade unions and

Office and the Dangerous Trades: Regulating Occupational Disease in Victorian and Edwardian Britain (Amsterdam 2002); idem, "Success or Failure? The Prosecution of the Early Factory Acts", Economic History Review, 38 (1985), pp. 423-427; idem, "State Intervention in MidNineteenth Century Britain: Fact or Fiction?”, Journal of British Studies, 23 (1983), pp. 63-83; P.W.J. Bartrip and T.P. Fenn, "Factory Fatalities and Regulation in Britain, I878-1913", Explorations in Economic History, 25 (1988), pp. 60-74. On trade unions see Curthoys, Governments, Labour, and the Law; Michael J. Klarman, "The Judges versus the Unions: The Development of British Labor Law, I867-1913", Virginia Law Review, 75 (1989), pp. I487I602; Jonathan Spain, "Trade Unionists, Gladstonian Liberals and the Labour Law Reforms of I875”, in Eugenio F. Biagini and Alastair J. Reid (eds), Currents of Radicalism: Popular Radicalism, Organised Labour and Party Politics in Britain, I850-1914 (Cambridge, I991), pp. 109-I33; Barry Jones and Michael Keating, Labour and the British State (Oxford, 1985).

Io. Though for compelling work on the weakness of the state in enforcing Factory Acts see P.W.J. Bartrip, "British Government Inspection, 1832-1875: Some Observations”, The Historical Journal, 25 (1982), pp. 605-626; 613-616; idem, "State Intervention in MidNineteenth Century Britain: Fact or Fiction”, The Journal of British Studies, 23 (1983), pp. 63-83; P.W.J. Bartrip and P.T. Fenn, "The Administration of Safety: The Enforcement Policy of the Early Factory Inspectorate, I 844-I864", Public Administration, 58 (1980), pp. 87-103; idem, "The Evolution of Regulatory Style in the Nineteenth Century British Factory Inspectorate", Journal of Law and Society, Io (1983), pp. 20I-222; and Stewart Field, "Without the Law? Professor Arthurs and the Early Factory Inspectorate”, Journal of Law and Society, I7 (1990), pp. $445-468$.

I I. Price, British Society, p. I 24.

I 2. Anne Digby, “The Local State”, in E.T.J. Collins (ed.), The Agrarian History of England and Wales, vol. 8, I850-I9I4, pt 2 (Cambridge, 2000), pp. I425-I464. As Price notes, "MidVictorian localism could thrive because of the limited reach of central government. Institutional links between the centre and the regions remained as weakly developed in the nineteenth century as they had in the eighteenth"; British Society, p. I83. For a discussion of the historical development of state power through a devolved legal system with community bases see Margaret R. Somers, "Citizenship and the Place of the Public Sphere: Law, Community, and Political Culture in the Transition to Democracy", American Sociological Review, 58 (1993), pp. 587-620. I3. A.H. Manchester, A Modern Legal History of England and Wales, 1750-1850 (London, 1980), pp. 160-161, 222-225; Thomas Skyrme, History of the Justices of the Peace (Chichester, I994), pp. 622-623. 
conspiracy, the local bench certainly was the touchstone of power. ${ }^{14}$ Given the considerable latitude provided to local authorities to exercise this power, it makes less sense to make national characterizations of a "weak" or "laissez-faire" versus a "strong" or "interventionist" state in economic affairs, than to analyze the scope and reasons for regional variations in the uses of the law. As Pat Hudson argues, "When one comes to analyse the role of the state directly and specifically in promoting British regional growth it is the role of local government at the county and sub-county level which requires attention." Is

The analysis below is part of a larger comparative project that examines the varied ways in which capitalists in mid-Victorian England, both large and small, and including both urban and rural employers, drew on the power of the local state to enforce work discipline, exert control in the labor market, and assert their authority in the employment relationship. One goal is to demonstrate that unfree labor, as constructed through master and servant and other laws, was vital for the development of particular industries given strategic considerations such as the flexibility of the labor supply and recruitment, a stable and dependable source of labor power, and the costs of extraction and non-productivity due to worker resistance. Legal servitude that is not forced labor - much as the increasing control through deskilling, technology, production games, the gender and racial/ethnic divisions of the labor force, and other mechanisms - helped secure the subordination of labor and sustain capitalist development in a number of industries. ${ }^{16}$

A second and allied goal is to demonstrate how this subordination depended upon local magistrates' and borough courts for the effective exercise of power. Employers who had access to sympathetic benches or who were themselves embedded in varying local elite networks of power giving them privileged access to the court, could rely on the law as an

I4. Curthoys, Governments, Labour, and the Law; Douglas Hay, "England, I 562-1875: The Law and Its Uses", in Hay and Craven, Masters, Servants, and Magistrates in Britain and the Empire, pp. 59-116; John V. Orth, Combination and Conspiracy: A Legal History of Trade Unionism, I72 I-I906 (Oxford, I99I).

I 5. Pat Hudson, "The Regional Perspective", in idem (ed.) Regions and Industries: A Perspective on the Industrial Revolution in England (Cambridge, I989), p. 30.

I6. My project focuses on those industries in which master and servant law was an active and regularized feature of the employment relationship. However, we should keep in mind that employers in many industries, both factory-based and craft-centered, relied on markedly different forms of stability and control in the workplace. James Jaffe has recently emphasized that employers in some artisanal trades such as printing focused on what he terms a "giftexchange" relationship. This was a bargain in which the employer allowed for discretion in the workplace and the worker exercised his skills in return. He notes that magistrates frequently used such informal agreements as the basis to arbitrate disputes without formal recourse to the law; James Jaffe, Striking a Bargain: Work and Industrial Relations in England I8I5-1865 (Manchester, 2000). 
answer to their labor problems. They turned to the local court when they lacked sufficient control of or predictability in securing labor in free markets and in control of the labor process. Part of the regional variability in the use of master and servant law as a solution, as I argue below, was assured access to dependable and sympathetic justices. This intersected with regional variations in the structure of labor markets, skill requirements for labor processes, technological development and expenditures in fixed capital, and a number of other considerations to produce a complex set of causal forces that determined the need to rely on the law as a means of labor control and discipline. In the end only detailed regional empirical studies of a variety of industries will provide us with sufficient insight to account for these variations.

A final goal particular to this case study is to clarify the importance of apprenticeship and youth labor, another form of unfree labor, in nineteenth-century English capitalist development. Though K.D.M. Snell has termed the debate over the decline of apprenticeship as one of the most "chaotic" in English social history, many economic historians offer a Whiggish view of the institution, suggesting that it was largely a relic of an early economic system. ${ }^{17}$ Clark Nardinelli, for example, straightforwardly asserts that,

The industrial revolution ended apprenticeship. The early factory masters employed an apprentice workforce because no other was available. Free children, however, rapidly replaced apprentices in the textile industries in the early nineteenth century. Furthermore, as modern industry replaced handicraft industry, the institution of apprenticeship began to disappear throughout the economy. ${ }^{18}$

With a few exceptions child labor in general, and pauper apprenticeship in particular, are seen as artifacts of the early nineteenth century, a phenomenon caused by a need for industrial labor and eventually obviated by technological advances. ${ }^{19}$ As Snell observes, the traditional system of

17. K.D.M. Snell, Annals of the Labouring Poor: Social Change and Agrarian England I6601900 (Cambridge, 1985), p. 230.

I8. Clark Nardinelli, "Were Children Exploited During the Industrial Revolution?", Research in Economic History, Io (1988), p. 259.

19. O. Jocelyn Dunlop, English Apprenticeship and Child Labour: A History (New York, I9I 2); Thomas E. Jordan, Victorian Childhood: Themes and Variations. (Albany, NY, 1987); Joan Lane, Apprenticeship in England, I600-1914 (Boulder, CO, 1996); Eric Hopkins, Childhood Transformed: Working-Class Children in Nineteenth-Century England (Manchester, 1994); Ivy Pinchbeck and Margaret Hewitt, Children in English Society, vol. 2: From the Eighteenth Century to the Children Act of 1849 (London, 1969); Lionel Rose, The Erosion of Childhood: Child Oppression in Britain I860-1918 (London, 1991); Mary B. Rose, "Social Policy and Business: Parish Apprenticeship and the Early Factory System I750-I 834", Business History, 3 I (1989), pp. 5-32; K.D.M. Snell, "The Apprenticeship System in British History: The Fragmentation of a Cultural Institution", History of Education, 25 (1996), pp. 303-32 I. For an argument that industrialists preferred to use children because of technological advances see 
apprenticeship was unmoored from its institutional roots to craft, parish, and family and mutated into a number of skill-training variants. To the extent that apprenticeship extended into the latter part of the nineteenth century, it has been depicted as a self-enforcing system by which youths (largely though not entirely males) were able to gain entrance into a trade in exchange for service. ${ }^{20}$

Certainly with the textile industries, mining, many workshop industries and agricultural labor increasingly regulated by parliamentary acts, the use of apprentice and youth labor became more problematic, and technological change diminished the demand for youth labor in other trades. However, during the mid-Victorian period there was a substantial increase in the number of male children under fifteen employed in navigation, dock work, and on the railways. Moreover, as many historians note, despite the ill-repute of pauper apprenticeships, they remained a potentially important means for parishes to reduce their fiscal burdens. ${ }^{21}$ This study illustrates how youth labor in general and a degraded form of apprenticeship in particular, could still be vital to the process of industrial expansion. As I demonstrate, this was particularly the case when apprentice labor could be disciplined and controlled through the law.

\section{MASTER AND SERVANT LAW}

Through the first three-quarters of the nineteenth century, land-based workers labored under a form of contractual agreement that was substantively unfree. ${ }^{22}$ While these laws had distant origins in the sixteenth century, in their current form they were part of a transformation of the law in the eighteenth and early nineteenth centuries that increased capitalists' capacity to hamper growing worker resistance. ${ }^{23}$ In effect, master and

Carolyn Tuttle, Hard At Work in the Factories and Mines: The Economics of Child Labor During the British Industrial Revolution (Boulder, CO, 1999).

20. Snell, "The Apprenticeship System in British History", pp. 315-317; Jane Humphries, "English Apprenticeship: A Neglected Factor in the First Industrial Revolution", in Paul A. David and Mark Thomas (eds), The Economic Future in Historical Perspective (Oxford, 2003), pp. 73-108.

21. Jordan, Victorian Childhood, pp. I24-I25; Lane, Apprenticeship in England, p. 81; Rose, "Social Policy and Business", p. 7; Hopkins, Childhood Transformed, pp. 179-180, 220.

22. Britain's many sea-based workers were covered by the Merchant Shipping Act as I discuss below.

23. For a detailed discussion of the development of master and servant law for specific trades in the eighteenth century and its generalization to virtually all forms of labor (excluding domestic service and the professions) in the I823 Master and Servant Act (4 Geo. IV c.34), see Hay, "England, I 562-1875", pp. 82-91. For complete texts of all the acts from I720-1823 see Charles J.B. Hertslet, The Law Relating to Master and Servant [...] (London, I 850), pp. 27-10I. As noted below, the law was amended in 1867 in response to trade-union appeals, changing the legal grounds for the imprisonment of workers, allowing workers to testify in their own defence, and requiring adjudication before two justices, among other changes. For these changes and detailed 
servant laws were newly codified forms of labor control passed directly in response to the pleas of employers in quite varied industries who confronted increasing problems of labor discipline. Until I 875 workers were criminally libel under the law for: (I) failure to enter service (based on a written contract); (2) leaving service without permission or proper notice; (3) misconduct and misbehavior; and (4) incompetence or misrepresentation of skill. The vast majority of cases probably fell under the second and third categories.

What was required in service devolved to a matter of customary practices for each trade and locale in the lieu of any written standards. ${ }^{24}$ As Carolyn Conley observes of the Victorian local criminal courts,

[...] the findings and actions of the criminal justice system were primarily determined by the values and priorities of the local community. Whether a particular action was defined and treated as a crime depended on a number of important factors, among which the written law was often the least important. ${ }^{25}$

As she suggests, local courts were generally guided by the interwoven concerns of respectability, order, and class. Justice was never rendered through the blunt instrument of class interest, but "respectability meant behaving in a manner according to one's status". ${ }^{26}$

In some regions the volume of such cases adjudicated by local magistrates prompted them to be quite knowledgeable mediators concerning labor arrangements and customs. However, in many areas, such as Hull, the magistrates could enforce a respectability that served employers' interests well, meting out justice with stringency. And this justice could sting. Workers were subject to dismissal, abatement of wages, and/or up to three months imprisonment with hard labor if convicted. High court rulings during the period also established that no punishment released the worker from his or her service obligation. ${ }^{27}$ As Hay observes, "By the

comparisons of the 1823 Act and the 1867 amendment (30 \& 3I Vict. c. I4I), see James E. Davis, The Master and Servant Act, I867 (London, I868).

24. Hay, "Master and Servant in England", p. 228; Simon "Master and Servant", pp. I6I-i62, 23 I; W.A. Holdsworth, The Law of Master and Servant; Including That of Trades Unions and Combinations (London, I876), pp. 30, 43, 72.

25. Carolyn Conley, The Unwritten Law: Criminal Justice in Victorian Kent (Oxford, 1991), p. vi. 26. Ibid., p. 173 .

27. Punishment was modified under the revised Act of $\mathrm{I} 867$, which provided for damages not available under the previous Act instead of the abatement of wages. It also changed the grounds for imprisonment to aggravated circumstances, though exactly what these constituted was left to the local magistrates. In some areas the number of prison sentences dropped substantially with this provision though, as we shall see, not in Hull; Hay, "Patronage, Paternalism, and Welfare", p. 36; Davis, The Master and Servant Act, pp. 49, 7I-74; Brian Napier, "The Contract of Service: The Concept and its Application" (D.Phil. thesis, University of Cambridge, 1975), pp. I22-I24. 
mid-ninteenth century $[\ldots]$ the taint of criminality ran through master and servant proceedings from the initiation of the process". ${ }^{28}$

Maritime workers faced a similar legal situation. The Merchant Shipping Act of I 854 imposed up to ten weeks imprisonment for unauthorized leave and twelve weeks and a forfeiture of all wages for desertion. It also empowered magistrates to order the forced return of the seaman to the ship to continue duty, and to permit the transfer of a seaman on board a vessel in the middle of serving a sentence should his labor be required by his master. Further, the Act provided for the master or ship owner to seize a seaman without warrant and hold him on board for twenty-four hours prior to a hearing, voiding basic civil liberties. This law remained in force until a clamor for revision in I880. ${ }^{29}$

Under both the Merchant Shipping Act and the Master and Servant Act employers were subject to civil sanctions for inadequate treatment, improper dismissal and failure to pay wages. ${ }^{30}$ These involved fines, voiding of contracts, and court-ordered payments, and as civil cases there were no aggregate statistics recorded of their frequency. In the Hanley borough court for the period the volume of charges by employers far outstrips claims by workers, and this is probably the case for almost all areas in the nineteenth century..$^{3}$

Annual Parliamentary reports show that for the mid-Victorian period until its repeal in i 875 there were generally around 9,000 to I I,000 cases which were within the range of convictions for petty larceny, breaches of the peace, various misdemeanors, and begging. ${ }^{32}$ For working people in

28. Hay, "Master and Servant in England", p. 238. See also idem, "England, I 562-1875", pp. 106-108.

29. Frederic P. Maude and Charles E. Pollock, A Compendium of the Law of Merchant Shipping (London, I 86I), pp. I I7-I 20; John Rule, "The Smackmen of the North Sea: Labour Recruitment and Exploitation in British Deep-Sea Fishing, 1850-1900", International Review of Social History, 2 I (1976), pp. 383-4I I, 40I.

30. There were more elaborate protections under the Merchant Shipping Act than for land workers because of the ways in which seamen could be preyed upon, including abandonment at foreign ports; Simon, "Master and Servant", p. I60; Maude and Pollock, A Compendium of the Law, pp. I24-i 56; W.T. Greenhow, The Shipping Law Manual (London, i863), pp. 24-33. 3I. Hay suggests that by the I860s employers were generating about 80 per cent of all complaints; Hay, "Master and Servant in England", p. 258. Whether this was true for the eighteenth century is open to question. Hay suggests that the ratio of complaints might well have been roughly equal, while Morgan and Rushton, in their analysis of an eighteenth-century Durham magistrate's books show a preponderance of claims by apprentices, servants, and other workers. Elsewhere, Rushton has argued that the majority of cases involving apprentices brought before the bench in the north-east in the seventeenth and eighteenth centuries were by the apprentices; Hay, "Patronage, Paternalism, and Welfare", p. 36; Gwenda Morgan and Peter Rushton, "The Magistrate, the Community and the Maintenance of an Orderly Society in Eighteenth-Century England", Historical Research, 75 (2003), p. 62; Peter Rushton, "The Matter at Variance: Adolescents and Domestic Conflict in the Pre-Industrial Economy of Northeast England, 1600-1800”, Journal of Social History, 25 (1991), pp. 89-106.

32. The returns are found in annual reports under "Judicial Statistics. England and Wales. 
the mid-Victorian era an experience with criminal justice, outside one concerning drinking or fighting, was about as likely to concern work as any other sphere of life. There was wide regional and industrial variation, and one town in which there was a high number of convictions was Hull.

As Table I overleaf demonstrates, beyond assault or drunkenness, the working people of Hull were as or more likely to be convicted summarily of a violation of master and servant law as of any other single criminal offence most often connected with their class. Moreover, proportionately master and servant convictions for these years hovered between 4 and 7 per cent of the town court's total summary convictions, which was between two and three times higher than the national percentage.

\section{THE CASE OF THE HULL TRAWLING INDUSTRY}

By I 872 this town of about I 25,000 people was the third largest port in England, shipping about 9 per cent of all its exports (amounting to $£_{23}$ million) and receiving almost 5 per cent of all imports (or £ 6.5 million). It specialized in exporting manufactured goods from the industrial north, as well as coal and cattle. Imports were largely raw materials, such as timber and cotton and foodstuffs, such as corn and oilseeds. Trade was anchored in the Baltic region, but there was also a substantial global network of shipping ties. This trade fostered a substantial seed-crushing industry of 37 mills, several extensive cotton hemp and flax manufactories (the largest employing I,500 hands), perhaps the largest concentration of furniture makers in the country, several large paint and coatings manufacturers, and of course a major shipbuilding industry for both steam and sailing ships, with the largest yard employing about 2,000 workers. In I 87 I transport employed almost one-quarter of the male workforce, metal trades and engineering I 4 per cent, the building trades io per cent, followed by other industries in the single digits. The upstart trawling industry employed less than 3 per cent of all males. 33

Hull had its share of both strikes and unionism during these years, particularly among skilled workers such as shipyard engineers, oil millers,

Police-Criminal Proceedings-Prisons. Returns for the year". As Hay notes, the ratio of master and servant prosecutions amounted to $\mathrm{I} 2$ to 32 per cent of all theft prosecutions, and this ratio would have been higher except that the "enormous expansion of summary convictions for theft had changed the denominator of the ratio"; Hay "England, I $562-1875$ ", p. I08.

33. Joyce Bellamy, "Occupations in Kingston Upon Hull, I84I-1949", Yorkshire Bulletin of Economic and Social Research, 4 (1952), p. 39; idem, The Trade and Shipping of NineteenthCentury Hull (York, 1971), pp. 31-34, 38-39; Raymond Brown, Waterfront Organisation in Hull, I870-1900 (Hull, I972); James J. Sheahan, General and Concise History and Description of the Town and Port of Kingston-upon-Hull (London, I864), pp. 284, 582, 586, 589-591, 596; David Starkey, "Ownership Structures in the British Shipping Industry: The Case of Hull, I $820-$ 1916", International Journal of Maritime History, 8 (1996), p. 73; The Trade and Commerce of Hull: Its Ships and Shipowners, Past and Present (Hull, I878, 2nd edn), pp. I I, I7, I I3-I I7. 
Table I. Number of summary criminal convictions by type reported to Parliament for Hull, I864-I87

\begin{tabular}{|c|c|c|c|c|c|c|c|c|c|c|c|c|}
\hline Type of conviction & 1864 & 1865 & 1866 & 1867 & 1868 & 1869 & 1870 & 1871 & 1872 & 1873 & 1874 & 1875 \\
\hline Assault on peace officer & 158 & 168 & 140 & 114 & 126 & 140 & 142 & 166 & 181 & 118 & 132 & 89 \\
\hline Assault, common & 234 & 267 & 190 & 166 & 166 & 146 & 146 & 379 & 485 & 503 & 510 & 424 \\
\hline Drunk and disorderly & 966 & 895 & 834 & 779 & 963 & 927 & 794 & 1,018 & 1,100 & 1,484 & 1,467 & 1,172 \\
\hline $\begin{array}{l}\text { Poor Law/neglecting } \\
\text { family }\end{array}$ & 18 & 7 & 4 & 5 & 16 & 10 & 12 & 15 & 9 & 21 & 12 & 15 \\
\hline Master and servant & 77 & 177 & 144 & 165 & 157 & 90 & 126 & 140 & 183 & 192 & 205 & 230 \\
\hline Larceny under $5 \mathrm{~s}$ & 83 & 80 & 76 & 117 & 122 & 125 & 107 & 140 & 113 & 119 & 101 & 132 \\
\hline Larceny above $5 \mathrm{~s}$ & 79 & 103 & 119 & 90 & 92 & 91 & 78 & 92 & 86 & 94 & 107 & 124 \\
\hline $\begin{array}{l}\text { Vagrancy act/ } \\
\text { prostitution }\end{array}$ & 76 & 81 & 107 & 72 & 64 & 55 & 66 & 141 & 95 & 99 & 112 & n.a. \\
\hline Vagrancy act/begging & 72 & 26 & 56 & 117 & 149 & 177 & 151 & 118 & 106 & 103 & 77 & n.a. \\
\hline $\begin{array}{l}\text { Total criminal } \\
\text { convictions }\end{array}$ & 2,812 & 2,683 & 2,482 & 2,468 & 2,624 & 2,507 & 2,746 & 3,722 & 4,168 & 4,406 & 4,445 & n.a. \\
\hline
\end{tabular}

Source: England and Wales, Police-Criminal Proceedings-Prisons, Judicial Statistics. Returns. 
and the building trades. However, it does not appear that the town was known for especially contentious labor relations. It had a higher proportion of unskilled to skilled labor than many other large English towns, and as a port had a substantial transient workforce. ${ }^{34}$ In the last decades of the century, during which time the local economy experienced its most significant growth spurt, strikes and union organizing became more prominent features in both engineering (including shipbuilding) and transportation. ${ }^{35}$ At the beginning of I 867 a Trades' Council was formed comprising 7 unions and about 650 members and a month later boasted an additional ro unions as members. By this period many of the larger trade groups had formed unions, including the seed-crushers, coopers, tailors, typographers, and various building trades. ${ }^{36}$ The prosperous years of the early i 870 s witnessed Hull engineers reorganizing under the banner of the United Marine Engineers' Association, and a variety of trades campaigned successfully for the nine-hour day. During this period the Lincoln Amalgamated Labour League also successfully established ties with many of the local unions. However, the fishing industry was never organized, and on the whole organized collective action was infrequent. ${ }^{37}$

During a few such events employers sought the assistance of the local bench, particularly during strike actions involving larger firms. They used prosecution as part of a repertoire of tactics to intimidate workers and cow strike leaders. ${ }^{38}$ The major shipbuilding firm, Humphry and Pearson, prosecuted striking workers in $\mathrm{I} 87 \mathrm{I}$. Company representatives successfully used master and servant law to force a group of platers back to work on the claim of insufficient notice. ${ }^{39}$ In May I 867 the North Eastern Railway Company summoned ten engineers, following the same strategy to quash a major strike of railworkers. ${ }^{4}$ On the whole, though, court

34. Brown, Waterfront Organisation in Hull, pp. Iо- I I.

35. The labourers at the largest shipyard, C \& W. Earle, had struck in I 864 for an advance, and two years later a major strike of 2,000 union and non-union engineers won advances from their employers; Edward Gillett and Kenneth A. McMahon, A History of Hull (Hull, 1989), pp. 333334. In 1872 railway workers founded a branch of the Railway Servants' Amalgamated Society and in 1874 the Amalgamated Labour League was founded; Hull and Eastern Counties Herald, 2I March i 872, 3 September i 874 .

36. Beehive, 16 September, 7 October 1865 , 30 March I 872; Hull and Eastern Counties Herald, 7 September 1865, I 3 December I866, I7 January, 24 February i 867.

37. Brown, Waterfront Organization in Hull, p. I6; Beehive, 8 November, 20 December, I 873 ; Hull and Eastern Counties Herald, 9, 16, 30 November, 7, I4, 21 December I871.

38. The Master and Servant Act was used by employers to break strikes by prosecuting for leave of absence without appropriate notice or permission; Hay, "Master and Servant in England", pp. 252-254; Simon, "Master and Servant", p. I7I. In a review of the changing relationship between judges and unions in the later nineteenth century, Michael Klarman observes that, "The draconian master-servant law was perhaps the most effective means of stemming worker insubordination": Klarman, “The Judges versus the Unions”, p. I493.

39. Hull and Eastern Counties Herald, 26 January, 9 February i 87 I.

40. The Commonwealth, 4 May i 867. 
records and newspapers show that capitalists in Hull's major industries resorted to such criminal prosecutions sparingly. Rather, the use of the law was highly concentrated in the much smaller fish trawling trade.

The trade was a relatively recent development in Hull's economic history, a product of the discovery of extensive fishing grounds in the deep waters off the Yorkshire coast in the I830s and I840s and the extension of the railways. The industry developed rapidly in Hull, Grimsby, and other ports in the i 860 s. In the early i 850 s there were only a few dozen fishing trawlers (or smacks as they were generally called) in Hull; by 1863 they numbered about 270 and by I 873 there were some 330 smacks. A new fully

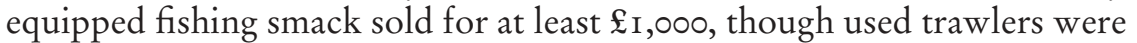
perhaps half to two-thirds of that price. The self-made masters of Hull's fishing trade often heavily mortgaged their vessels, "working off" the payments with each catch. The proportion of fixed to variable capital was actually higher in fishing than cotton manufacturing, and from the start many ship owners found themselves in highly leveraged positions. ${ }^{4}$ Newspaper accounts for the period point to at least fifteen smack-owners filing for bankruptcy. ${ }^{42}$

It is difficult to reconstruct the finances of these smack-owners, but a rough indication can be gleaned from the Registry of Ships for the port of Hull during the period. All smacks were registered with the port as well as a record their financing (including their mortgages) and sale. ${ }^{43}$ Reconstructing the record of the smack-owner responsible for the most convictions of fishing apprentices during the period (see Table 7, p. 272), Thomas Halfyard, shows a dynamic web of financial entanglements.

Between I 860-i 875 Halfyard was involved in eighteeen sales of smacks and underwrote twenty-three mortgages for these and other vessels. On the other side of the ledger he took out thirteen mortgages himself, about

4I. Kew, British Public Record Office MH/32/99, Baldwin Fleming, Correspondence and Papers Related to the North Midland District; "Treatment of Pauper Apprentices in the Grimsby Fishing Trade”, I9 June I873, fo. 45; Alfred Ansell, On Trawling (London, I883), p. 7; David Boswell, Sea Fishing Apprentices of Grimsby (Grimsby, 1973), p. I 5; Edmund Holdsworth, Deep-Sea Fishing and Fishing Boats (London, r874), pp. 25, 69, 257; Robb Robinson, $A$ History of the Yorkshire Coast Fishing Industry, I780-I9I4 (Hull, I987), pp. 47-48; Robb Robinson, Trawling: The Rise and Fall of British Trawl Fishery (Exeter, 1996), p. 67; "Report of the Commissioners on the Sea Fisheries of the United Kingdom", British Parliamentary Papers [hereafter BPP] i 866 XVIII, (3596-I), pp. I56, I63; Hull and Eastern Counties Herald, 7 August, I 3 November I 873 .

42. The vast majority of these were before 1870 though; Hull and Eastern Counties Herald, I January, 24 March, 7 April, 26 May, 6 June I864; 22 February, I8 October I865; I 8 April, 27 June, Is August, I4, 28 November I 867; I January, I I February, Io June, I 2 October, I I, Is November I 869; 5 May I874.

43. Kingston upon Hull City Archives, Registry of Ships DPC/I/I 5, I 858 - I 86 I, Port Number: I 8/58 to 8/6i ; DPC/I/I6, I86I-I864, Port Number: 9/6I to I 5-64; DPC/I/I7, I 864-I 867, Port Number: I6/64 to I $5 / 67$; DPC/I/I 8, I867-1871, Port Number: $9 / 67$ to 64/7I; DPC/I/I9, I87II 873 , Port No. $65 / 7$ I to $60 / 73$; DPC/I/20, I $873-1876$, Port No. $61 / 73$ to $43 / 76$. 
two-thirds of the them from a London fish factor. Overall, Halfyard appears to have maintained a positive balance sheet of several hundred pounds over much of the period between his own mortgage payments and the income from his borrowers. However, in the early i 870 , with a series of mortgage payments due on vessels, the balance might have tipped the other way. Halfyard's mortgages for vessels he purchased were generally $£_{400}$ to $£_{500}$ at 5 per cent, while those he underwrote when selling vessels were generally in the $£ 600$ to $£ 700$ range. His loans were usually paid back within a three-year time span, though those of his buyers were often over four to five years. It is impossible to determine the percentage of his total income that Halfyard generally received through the selling and underwriting of his older fishing smacks.

The ship registers do suggest a very active market in smacks and one in which larger fleet owners were cogs in the chain of a growing port fleet. They depict a trade in which credit sources were largely internal, with loans mostly provided by smack-owners selling vessels or fish merchants. ${ }^{44}$ The sheer volume of this trade, which increases over the course of the period, hints at a growing speculative market with the expansion of the industry. However, exactly how much capital was represented by a port's fleet in this period is open to question. A Grimsby smack-owner, testifying before the Commissioners of Sea Fisheries in I866, noted that because of highly speculative loans $£_{300,000}$ invested in smacks had only procured about $£_{100,000}$ worth of vessels. ${ }^{45}$ A major Hull smack-owner, Alfred Ansell, reported in I 869 that 242 Hull smacks were worth about $\mathfrak{E}_{\text {I } 49,000 .{ }^{46}}$

The rate of return on investment is also unclear. William Markchow, a Hull smack-owner testifying in I866, claimed that 5 per cent could be achieved with careful management. In a latter report the Inspectors for the Commissioners suggested that for the trade as a whole a smack could net $£ 70$ to $£ 80$ a year, though testifying before a Parliamentary committee in the early i 880 s, a Grimsby smack-owner maintained that his average profit rate over the previous five years was at best 2 per cent. ${ }^{47}$ While rates of return might vary, however, mortgage payments were a constant. Many smack-owners depended on regular runs to stay afloat.

44. Joyce Bellamy has noted that the industry was largely detached from the other commercial sectors in the town; Bellamy, The Trade and Shipping, p. 56.

45. "Report", BPP i 866 XVIII, pp. I 56, i60.

46. Hull and Eastern Counties Herald, i I November I 869. To place this amount in perspective, one shipbuilding firm, Hull Iron Works and Shipbuilding Co. Ltd., was capitalized at $£_{\mathrm{I}}$ million in I 864, and it was by no means the largest; Hull and Eastern Counties Herald, 28 April I 864. 47. Markchow also observed that large capitalists did not invest in the trade affirming its petty bourgeois foundations; "Report of the Commissioners", BPP I 866 XVIII, p. I60; "Report of the Inspectors of Fisheries and Commissioners for Sea Fisheries. (Frank Buckland and Spencer Walpole)", BPP i 878-79 XVII, (2449), p. I I 2; "Report of a Committee [...] To inquire into [...] the relations between the Owners, Masters and Crews of Fishing Vessels [...]", BPP г 882 XVII, (3432), p. 60. 
As a contemporary commercial review noted, "There is little romance with the history of this trade". ${ }^{8}$ The work was considered some of the least desirable in the port, and despite its rapid growth smack-owners had difficulties recruiting reliable crews. These crews were small laborintensive units, consisting of only five including the skipper. Between solo voyages in the winter generally lasting ten days to three weeks, to fleet voyages of thirty or more smacks in the spring and summer going from eight to as many as fifteen weeks, smacks were at sea at least forty weeks a year, regardless of the weather. The crew was housed in a single small cabin in often miserable conditions, and remained in their work clothes throughout the voyage in order to respond quickly to orders. The cabins themselves were frequently flooded, and hands complained of inadequate maintenance of the vessels. Such small vessels were not subject to port regulation or inspection. A full day at work frequently involved at least two trawls, one during the day and one at night, which in bad weather could take two to three hours, and left little time for anything besides navigation, maintenance, meals, and sleep. The historian, John Rule quotes one observer of the trade describing the routine at sea as "suffering - monotonous ceaseless suffering".49 Moreover, given the small size of the boats and periodic transference of boxed catch by small boats to cutters for shipping, the work was extremely dangerous, ten times more so than mining..$^{\circ}$ From I876I882, for example, 304 men and boys sailing on Grimsby fishing smacks perished. ${ }^{\mathrm{I}}$

Adult crew members, generally the skipper, the second, and sometimes the third hands, received shares of the gross from the catch (net of deductions for provisions), with the smack-owner receiving the remainder. This assured their interests were aligned with the smack-owner. However, casual adult labor for the lower positions was considered too unreliable,

\footnotetext{
48. Trade and Commerce of Hull, p. I33.

49. Rule, "The Smackmen of the North Sea", p. 385.

50. During fleet voyages, which could encompass as many as seventy boats and lasting perhaps eight weeks, smacks would regularly offload boxes of their iced catch to cutters which would speed the fish to a principal port for sale. Boxes were placed in small boats manned by a couple of hands who navigated them to the waiting cutters. Fishermen objected to the system, particularly during the winter, because of the precariousness of negotiating the sea; PRO MH/32/99, "Treatment of Pauper Apprentices", fos 8, 51; Ansell, On Trawling, pp. 19-20, 22; Boswell, Sea Fishing Apprentices, pp. I0, 93, 96; Holdsworth, Deep-Sea Fishing, pp. 257-26r; Pamela Horn, "Pauper Apprenticeship and the Grimsby Fishing Industry, I870 to 1914", Labour History Review, 6r (1996), p. I76; Leone Levi, The Economic Condition of Fishermen (London I 883), p. 26; Robinson, Trawling, p. 71; Rule, "The Smackmen of the North Sea", pp. 384-387.

51. Robinson, Trawling, p. 56. During the period under study the local paper reported a number of apprentice deaths, though probably not nearly all of them; Hull and Eastern Counties Herald, 20 April I870, 20 April I871, I9 December I872, 24 April, 7 July, i I September, 25 December I873, 7 May, 29 October, 3 December 1874.
} 
and smack-owners generally could not compete with the shipping industry's going wages for able seamen. Needing a cheap and secure labor force to fill out the crews, smack-owners turned to the apprenticeship system. ${ }^{2}$ As Rule comments, "the smackowners solved the problem of labour supply in a way which strikingly recalls the methods of the factory masters of the early Industrial Revolution: they relied on poor-law apprentices". 53

By the I860s there were two forms of apprenticeship, indoor and outdoor. The former group were housed with their master (generally a lesser smack-owner) who, in addition to room and board, was responsible for all other basic provisions such as clothing for both sea and shore. Outdoor apprentices received wages of between 7 shillings and 16 shillings per week in lieu of having their room and board provided. Typically, they were bound to fleet owners, though indoor apprentices after the age of seventeen or eighteen might request a change to this status. Apprentices of either type were the fourth hands and cooks (and sometimes served the position of third hand as well). The former was responsible for watch, handling the smack in good weather, steering the small boat, taking soundings, gutting fish, and other tasks. The apprentice cook was the lowest hand and newest member who assisted the fourth hand, cleaned the deck and performed basic maintenance, and coiled the warp net when it was retrieved. Smack-owners were not obliged to pay their apprentices any wages, but it was customary that they were to receive a portion of the stockerbait, or money received at port for the sale of inferior fish. While not required, a modest amount of weekly pocket money was also traditional, especially for older apprentices. ${ }^{54}$

As a labor source they were frequently as capable as a grown man, though training did take several years and the return on the initial sunk investment was largely during the second half of the apprentice's term. Apprenticeship systems in the nineteenth century were clearly never free labor, and the trawling industry's was no exception. Estimates vary, but at least one-half of all apprentices were bound by their parents and were generally locals. However, as the trade rapidly expanded in the 1870 s, it increasingly came to rely on Poor Law Unions, reformatories, and other institutions as a labor source, and was indiscriminate in its recruitment. The lack of experience at sea made many such apprentices only a liability

52. While the system was started with the inception of the trade in the I 840 , it became common after it was used to break strikes of fishermen's unions in I 852 and I 856 ; Robinson, Trawling, p. 75 . 53. Rule, "The Smackmen of the North Sea", pp. 391, 405; Ansell, On Trawling, p. I9; Holdsworth, Deep-Sea Fishing, p. 258; Trade and Commerce of Hull, p. 134; "Report of a Committee", BPP i 882 XVII, p. 28.

54. PRO MH/32/99, Fleming, "Treatment of Pauper Apprentices", fos I0, I5-I7, 20; Boswell, Sea Fishing Apprentices, p. 27; William Chance, Children Under the Poor Law (London, 1895), p. 28 I; Rule, "The Smackmen of the North Sea”, p. 386. 
to themselves once at sea.55 Pamela Horn suggests that pauper apprentices were more valued because they were more easily subject to coercion, and the historian of the industry, Robb Robinson, observes that "Many apprentices were treated by the smack-owners as their personal property". 56

With some hyperbole, a contemporary London paper pronounced the apprentice system in the trawling industry as "a system of slavery as infamous as any system of slavery every devised". 57 Complaints about maltreatment by crew members were common, and many fisherlads preferred to commit crimes or refuse to obey orders so that they would be sent to jail rather than to sea. Increasingly, many absconded completely or ran away as the smacks embarked. ${ }^{8}$ Those disposed toward the industry argued that charges of cruelty were often inventions of apprentices to break their binding, and that troublesome and confrontational fisherlads often drove the crew to administer tough discipline. "I quite believe", noted Baldwyn Fleming in his report on the Grimsby pauper apprentices, "that many punishments which look serious when the subject of magisterial investigation have been inflicted with a rough and ready hand - perhaps with undue severity - but with no thought or intention of malicious cruelty". And he maintained that all the apprentices he interviewed stated that they "were fully aware that if ill-treated they would have no difficulty in obtaining redress".59 Hull apprentices frequently claimed abuse as a reason for absconding.

On occasion, an adult hand would be prosecuted by an apprentice for abuse as an assault, since the more severe cases generally involved beatings (often with a rope and termed "rope-ending"). During the years reported here there were at least a dozen such prosecutions, all involving assaults of

55. PRO MH/32/99, Fleming, "Treatment of Pauper Apprentices", fo. 23; "Report of a Committee", BPP I882 XVII, pp. 2-4; Boswell, Sea Fishing Apprentices, pp. 49-50, 58, 76; Robinson, Trawling, pp. 55-6.

56. Horn, "Pauper Apprenticeship", pp. I77-180; Robinson, Trawling, p. 58. This assumption of property in the apprentice was reflected in the questioning of Henry Toomes, mayor of Hull and a smack-owner, before the I 882 Parliamentary Committee, when he was asked, "No man should own an apprentice who does not own a smack or part of one?", (emphasis added); "Report of a Committee", BPP i 882, XVII, p. 86.

57. Horn "Pauper Apprenticeship", p. I 87; Likewise David Boswell, an historian of the trade for nearby Grimsby, has termed these apprenticeships "as much a peculiar institution [...] as was slavery in the United States"; Boswell, Sea Fishing Apprentices, p. 5.

58. Ibid., pp. 67, 96, 104, I07, I17; Horn, "Pauper Apprenticeship", pp. 184-186; Rule, "The Smackmen of the North Sea", pp. 395-397, 403. One major smack-owner, Alfred Ansell, appearing before the magistrates during an absconding case, noted that many fisherlads preferred jail time particularly "in the winter, when the weather is rough, rather than at sea"; Hull and Eastern Counties Herald, is December I 864.

59. PRO MH/32/99, Fleming, "Treatment of Pauper Apprentices", fos 26-27; see also "Report of a Committee", BPP i882, XIV, p. I8. 
some form. ${ }^{60}$ Most commonly these adult hands were ordered to find sureties of between $£_{2} 0$ and $£_{100}$ to keep the peace, though sometimes they were released on their own recognizance. In two cases fines of between 20 shilings and 50 shillings were exacted, the latter for the stabbing and pitching overboard of a fisherlad by a captain. The most severe punishment was meted out to a smackhand who hit an apprentice over the head with a poker, cut a piece of flesh out of his arm with a belt, rubbing saltpeter in the wound and eventually threw the boy into the sea. Apologizing and admitting drunkenness, he was given two months of hard labor, a sentence that, as we shall see, was commonly administered to the fishing apprentices themselves for absconding. When a smack-owner fired a skipper or other adult hand for mistreating an apprentice the abuser was readily hired by another owner, given the constant need for experienced labor. ${ }^{6 \mathrm{I}}$

In addition to the rough conditions and often poor treatment, older apprentices came to resent their comparatively paltry compensation. Smackhands and able seamen, who were often not much older, earned substantially more. During the back years of their terms, when they became most valuable to their masters, apprentices fully realized the extent of their exploitation. Absconding was seen by many apprentices as a means of rectifying this injustice as well as escaping their demeaning circumstances. As the number of apprentices increased, so too did the problems of keeping them compliant and bound for their full service. One smackowner reported that a deserting apprentice could cost him $£_{3} \circ$ to $£_{5} \circ$ a week in replacement wages and lost revenue, a considerable sum for a small capitalist. $^{62}$

To maintain this system of cheap labor smack-owners turned to the borough court headed by the stipendiary magistrate, Thomas H. Travis. As the court for cases of summary jurisdiction, charges under the Master and Servant and Merchant Shipping Acts were adjudicated before it. ${ }^{63}$ Stipendiary magistrates were modeled on the professionalized London

60. In late I 864 and early I 865 the skipper and smack-owner, Thomas Hamlyn, and his second hand John Anderson were brought before the bench on a charge for the death of an apprentice named Kisner. However, at the time the court deemed there was insufficient evidence. It is unlikely that Hamlyn was convicted of this charge, since court records show him as a prosecutor of fisherlads in 1866 and in intermittent years throughout the period; Hull and Eastern Counties Herald, 22 December I864, 5, I 2 January i 865.

6r. Boswell, Sea Fishing Apprentices, p. I09; Rule, "The Smackmen of the North Sea", p. 398; Hull and Eastern Counties Herald, 27 June, I 2 December i 867; 30 January i 868; 16 December I 869; 8 September I 872; I 3 February I 873; I6 July, 20 August I 874; 25 February I I November I875; Kingston upon Hull City Archives, Magistrates' Court Minute Books DPM/ı/89, I6 February I871, DPM/I/93, 2 September I 872.

62. "Report of a Committee", BPP i 882 XVII, p. 57.

63. Under the Master and Servant Act, workers could also sue for wages in the county court which was maintained for small claims. I have recorded a small number of such cases from the local papers for the study years, but they pale in volume to those before the local magistrates. 
metropolitan judiciary. As opposed to local borough justices, stipendiaries were experienced barristers who were paid a substantial salary to preside over local courts or circuits. Parliament authorized their appointment at the request of the local municipality or area, and they had lifetime terms. Despite the legal machinery for their installation, only ten stipendiaries had been appointed by the passage of the Stipendiary Magistrates Act of I 863, which extended the possibilities for such appointments. Where they did exist, as in Hull, they exercised a major presence in the local justice system. ${ }^{64}$

Travis was first appointed as stipendiary magistrate in I 854 . He presided over the bulk of the borough cases, though Hull also had a number of magistrates appointed from the ranks of the borough alderman. ${ }^{65}$ In reference to a dispute over increasing his salary, the Hull and Eastern Counties Herald observed that "of all the unpopular men in Hull, it may truly be affirmed that Mr Travis enjoyed the least amount of public favour", though he clearly had a group of supporters in borough government. ${ }^{66}$ In addition, there are indications that he was integrated with the local commercial elite through charitable institutions. In a couple of respects Travis models Conley's characteristics of Victorian justice mentioned above. In civic life Travis appeared as a stern moralist, speaking out against the scourges of criminality and drunkenness. ${ }^{67} \mathrm{He}$ envisioned himself as a strict and impartial upholder of the law, and so far as that benefited working people, a champion of their interests. As he noted in a worker intimidation case against shipyard strikers, "He would stand on the side of the men whenever and by whomsoever they were tyrannised

64. Stanley French, "The Further History of Stipendiary Magistrates", Criminal Law Review, I 4 (1967), pp. 227-229, idem, "The Further History of Stipendiary Magistrates, Pt 2", Criminal Law Review, I 4 (1967), p. 270; Manchester, A Modern Legal History of England and Wales, pp. 77-78. Smack-owners were not represented among the borough magistrates, and thus could not impress their influence directly as did major employers in other towns, as I have demonstrated in Hanley. Additionally, they do not seem to have been among the political elites. Two large smack-owners, Alfred Ansell and Henry Toozes (of Vivian \& Toozes) were leading members of the South Myton Reform Association, this being the ward with the largest number of electors and the highest concentration of smack-owners. Both were elected councillors for the district, along with their fellow smack-owner Christopher Pickering, in the early i 870 s. They were all Liberals, the normally dominant political force in the borough. However, there is no indication that as a voting bloc they were key players in local politics, or that they had any indirect influence on the borough magistrates; Hull and Eastern Counties Herald, 3 October I 868; I 8 February, I I November I869; 6 November I873; I January, 26 February, Is October, I 2 December I 874; 9 November I 875 .

65. Exactly who should be appointed was a subject of periodic squabbling; Hull and Eastern Counties Herald, 7, 26 July i 866; 8, 22, June i 87 I.

66. 2I June i 866. On several occasions over this period there were rancorous debates about increasing the salary of the stipendiary and his clerk that divided the borough council; Hull and Eastern Counties Herald, 9 March I 865, 26 July i 866, 5 June I 873.

67. Hull and Eastern Counties Herald, I January i 864, 2 August, 2I October I869. 
Table 2. Outcomes of workers' wage claims before Hull borough court, I $864-I 875$

\begin{tabular}{lcccll}
\hline Year & $\begin{array}{c}\text { Total } \\
\text { cases }\end{array}$ & $\begin{array}{c}\text { Judgement for } \\
\text { workers }\end{array}$ & Dismissed & Settled & Other \\
\hline 1864 & 105 & $75(71) \dagger$ & $24(23)$ & $1(1)$ & $5(4)$ \\
1865 & 83 & $43(52)$ & $37(45)$ & $2(2)$ & $1(1)$ \\
1866 & 81 & $57(70)$ & $21(26)$ & $3(4)$ & 0 \\
1867 & 60 & $40(67)$ & $15(27)$ & $5(6)$ & 0 \\
$1868^{\mathrm{a}}$ & 21 & $13(62)$ & $6(18)$ & $2(10)$ & 0 \\
$1869^{\mathrm{a}}$ & 23 & $13(56)$ & $5(22)$ & $5(22)$ & 0 \\
1870 & 72 & $54(75)$ & $12(17)$ & $6(8)$ & 0 \\
1871 & 61 & $38(62)$ & $16(26)$ & $6(10)$ & $1(2)$ \\
1872 & 41 & $21(51)$ & $10(24)$ & $8(20)$ & $2(5)$ \\
1873 & 46 & $26(57)$ & $14(30)$ & $5(11)$ & $3(7)$ \\
1874 & 75 & $47(63)$ & $20(26)$ & $8(11)$ & $0(8)$ \\
1875 & 52 & $37(71)$ & $7(13)$ & 0 & $8(16)$ \\
\hline
\end{tabular}

Source: Hull City Archives, Hull Magistrates' Court Minute Books, DPM/r/76-83, 85-91, 93-4 96-102

$\dagger$ As a percentage of annual total cases

a January-June and December only

over; and on the other hand, he would stand on the side of the masters whenever an attempt was made to do them wrong". ${ }^{68}$ When workers could clearly demonstrate wage claims Travis readily ruled in their favor, as demonstrated by the percentages in Table $2 .{ }^{69}$

As Table 2 shows, workers were successful in winning claims for unpaid wages between half and two-thirds of the time, with the bench arbitrating a settlement in roughly io per cent of the cases. As Hay suggests, many magistrates sought to portray themselves as indifferent arbitrators in work disputes. ${ }^{70}$ Where non-payment of wages was clear, Travis and other magistrates could maintain their stance as impartial and strict upholders of the law, a position which they hoped would buttress their convictions of workers. However, Travis's stance of strict adherence and his emphasis on moral propriety set him up as a ready conduit for those who sought to use master and servant law as a means of labor control. $7^{\mathrm{I}}$ More particularly, by

68. Hull and Eastern Counties Herald, 9 February I $87 \mathrm{I}$.

69. Statistics derived from annual parliamentary reports: Judicial Statistics England and Wales, Police-Criminal Proceedings-Prisons, returns for the year; BPP i 865, LII. [3534] 445; BPP i 866 LXVIII, [3726] 48 ; BPP i867 LXVI, [3930] 735; BPP i867-I868 LXVII, [470I-I] 947; BPP I867-1868, LXVII [470I] 737; BPP I 868-i 869, LVIII [4203] 737; BPP г 870, LXIII, [195] 525; BPP г 87I, LXIV [442] I; BPP i 872, LXV [600] I; BPP г 873, LXX, [87I] I; BPP I 874, LXXI [1055] i; BPP i875, LXXXI, [i3is] i; BPP i876, LXXIX, [i595] i.

70. Hay, "Patronage, Paternalism, and Welfare", p. 36.

71. Deputy Stipendiary Wrangham, who substituted for Travis on a number of occasions, seems to have adopted essentially the same posture concerning labor cases. As he noted in a master and 
the latter part of the period under study he made it quite clear that his sympathies for fishing apprentices had worn thin. At a hearing in early March of 1873 ,

Mr. Travis remarked that it was very well for people to talk about the hardships fisherlads had to undergo; probably some of the good people had never been in police court themselves. Let them hear both sides, and then come to a conclusion. He had had experience of thousands of cases, and he confessed that his feelings were with the boy when he first commenced, but they were not so now. The balance of good was decidedly with the masters..$^{2}$

To analyze the centrality of master and servant prosecutions to the fish trawling industry I have compiled data on all labor cases heard before the court from I 864 to 1875 using the Hull magistrates' clerk's minute books. ${ }^{73}$ I have supplemented this data set by collecting all labor cases mentioned in the weekly "Police Reports" section of the Hull and Eastern Counties Herald, which provides summaries of many of the cases heard before the borough court over the previous week. A review of all labor cases before the court from I864-1875 and of the fishing trade cases in particular reveals the extent to which the latter industry relied on the court as a means of labor control.

Table 3 shows the percentages of cases all master and servant prosecutions that involved disorderly apprentices and the percentage of these cases in turn that were of fisherlads. The numbers are bluntly telling. Virtually all prosecutions during these years were of disorderly apprentices and roughly three-quarters were of fisherlads, despite the fact that they constituted at most no more than I per cent of the entire male laboring population of Hull. Moreover, assuming a contemporary estimate that there were about 750 apprentices in the mid I 870 , then about 20 per cent of this group was caught up in the criminal justice system for almost all of these years. ${ }^{74}$

Tables 4 and 5 overleaf can be used to compare the sentences meted out

servant prosecution concerning a shipyard apprentice, "In olden times the apprentice was the domestic servant of the master, and he should contend strictly that in the present day an apprentice was bound to work at all reasonable times. This was a most important principle"; Hull and Eastern Counties Herald, 3 October 1867.

72. Hull and Eastern Counties Herald, 6 March 1873.

73. Case data extracted from Kingston upon Hull City Archives, Magistrates' Court Minute Books, DPM/I/76-83, 85-91, 93-94 96-102, I864-1875.

74. Trade and Commerce of Hull, p. I32. Despite their readiness to prosecute, smack-owners were frustrated with the legal machinery to do so. Under the Master and Servant Act a summons had to be issued for a servant believed to have left work without permission. If the summons could not be delivered a warrant could then be obtained. Smack-owners complained that they were required to take out summonses for absconding apprentices, knowing full well that they were fleeing, and that the possibility of having a policemen arrest them in the process was diminished since they had to return to court for a warrant; Hull and Eastern Counties Herald, 2 October, I 3 November I873. 
Table 3. Number of master and servant prosecutions by type, I864-I875

\begin{tabular}{|c|c|c|c|c|c|c|c|c|c|c|c|c|c|}
\hline Type of prosecution & 1864 & 1865 & 1866 & 1867 & $1868^{\mathrm{a}}$ & $1869^{\mathrm{a}}$ & 1870 & 1871 & 1872 & 1873 & 1874 & 1875 & Total \\
\hline All master and servant cases & 112 & 175 & 171 & 161 & 89 & 56 & 131 & 125 & 152 & 170 & 199 & 257 & 1,798 \\
\hline All disorderly apprentices & $\begin{array}{l}110 \\
(98)^{\mathrm{b}}\end{array}$ & $\begin{array}{l}169 \\
(97)\end{array}$ & $\begin{array}{l}170 \\
(99)\end{array}$ & $\begin{array}{l}144 \\
(88)\end{array}$ & $\begin{array}{r}86 \\
(97)\end{array}$ & $\begin{array}{r}55 \\
(98)\end{array}$ & $\begin{array}{c}131 \\
(100)\end{array}$ & $\begin{array}{l}120 \\
(96)\end{array}$ & $\begin{array}{l}149 \\
(98)\end{array}$ & $\begin{array}{l}166 \\
(98)\end{array}$ & $\begin{array}{l}181 \\
(91)\end{array}$ & $\begin{array}{l}243 \\
(95)\end{array}$ & $\begin{array}{c}1,724 \\
(96)\end{array}$ \\
\hline Disorderly fishing apprentices & $\begin{array}{c}55 \\
(50)^{\mathrm{c}}\end{array}$ & $\begin{array}{l}118 \\
(70)\end{array}$ & $\begin{array}{l}114 \\
(67)\end{array}$ & $\begin{array}{l}102 \\
(71)\end{array}$ & $\begin{array}{r}68 \\
(79)\end{array}$ & $\begin{array}{r}44 \\
(80)\end{array}$ & $\begin{array}{c}97 \\
(74)\end{array}$ & $\begin{array}{r}96 \\
(80)\end{array}$ & $\begin{array}{l}110 \\
(67)\end{array}$ & $\begin{array}{l}139 \\
(84)\end{array}$ & $\begin{array}{l}161 \\
(89)\end{array}$ & $\begin{array}{l}198 \\
(81)\end{array}$ & $\begin{array}{c}1,302 \\
(76)\end{array}$ \\
\hline
\end{tabular}

Source: Hull City Archives, Hull Magistrates' Court Minute Books, DPM/I/76-83, 85-91, 93-94, 96-102.

a January-June and December only

$b$ As a percentage of all master and servant cases

c As a percentage of all disorderly apprentice cases 
Table 4. Outcome of prosecutions of Hull fishing apprentices I864-I875

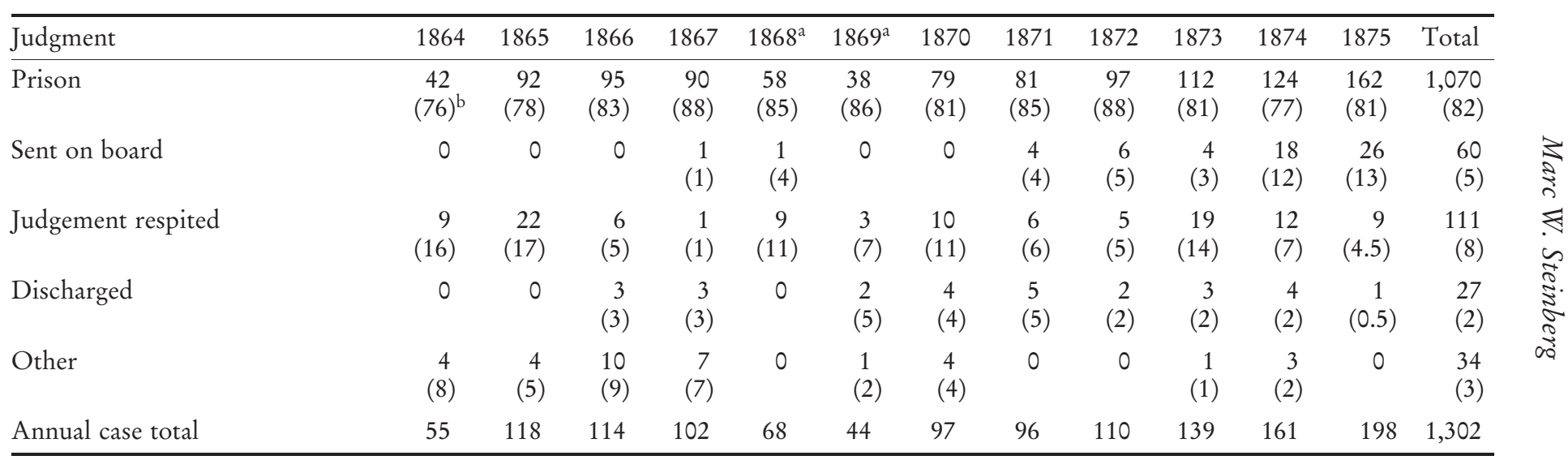

Source: Hull City Archives, Hull Magistrates' Court Minute Books, DPM/r/76-83, 85-91, 93-4 96-102

a January-June and December only

b As a percentage of annual total 
Table 5. Outcome of prosecutions of seamen under Merchant Shipping Act 1864-1875

\begin{tabular}{|c|c|c|c|c|c|c|c|c|c|c|c|c|c|}
\hline Judgment & 1864 & 1865 & 1866 & 1867 & $1868^{\mathrm{a}}$ & $1869^{a}$ & 1870 & 1871 & 1872 & 1873 & 1874 & 1875 & Total \\
\hline Prison & $\begin{array}{c}23 \\
(56)^{\mathrm{b}}\end{array}$ & $\begin{array}{l}22 \\
(48)\end{array}$ & $\begin{array}{l}25 \\
(58)\end{array}$ & $\begin{array}{c}16 \\
(53)\end{array}$ & $\begin{array}{c}8 \\
(58)\end{array}$ & $\begin{array}{c}3 \\
(25)\end{array}$ & $\begin{array}{c}8 \\
(24)\end{array}$ & $\begin{array}{l}25 \\
(37)\end{array}$ & $\begin{array}{c}16 \\
(50)\end{array}$ & $\begin{array}{c}8 \\
(27)\end{array}$ & $\begin{array}{l}14 \\
(28)\end{array}$ & $\begin{array}{l}16 \\
(30)\end{array}$ & $\begin{array}{l}184 \\
(41)\end{array}$ \\
\hline Sent on board & $\begin{array}{c}11 \\
(27)\end{array}$ & $\begin{array}{c}12 \\
(26)\end{array}$ & $\begin{array}{c}9 \\
(21)\end{array}$ & $\begin{array}{c}8 \\
(27)\end{array}$ & $\begin{array}{c}3 \\
(21)\end{array}$ & $\begin{array}{c}5 \\
(42)\end{array}$ & $\begin{array}{c}16 \\
(47)\end{array}$ & $\begin{array}{l}29 \\
(43)\end{array}$ & $\begin{array}{c}8 \\
(25)\end{array}$ & $\begin{array}{c}9 \\
(30)\end{array}$ & $\begin{array}{l}23 \\
(46)\end{array}$ & $\begin{array}{l}31 \\
(58)\end{array}$ & $\begin{array}{l}164 \\
(36)\end{array}$ \\
\hline Judgement respited & $\begin{array}{c}1 \\
(2)\end{array}$ & $\begin{array}{c}6 \\
(13)\end{array}$ & 0 & 0 & $\begin{array}{c}2 \\
(14)\end{array}$ & $\begin{array}{l}1 \\
(8)\end{array}$ & $\begin{array}{c}7 \\
(20)\end{array}$ & $\begin{array}{l}5 \\
(7)\end{array}$ & $\begin{array}{c}6 \\
(19)\end{array}$ & $\begin{array}{c}7 \\
(23)\end{array}$ & $\begin{array}{c}5 \\
(10)\end{array}$ & $\begin{array}{l}1 \\
(2)\end{array}$ & $\begin{array}{l}41 \\
(9)\end{array}$ \\
\hline Discharged & $\begin{array}{c}2 \\
(5)\end{array}$ & $\begin{array}{c}1 \\
(2)\end{array}$ & 0 & $\begin{array}{l}2 \\
(7)\end{array}$ & 0 & $\begin{array}{c}2 \\
(17)\end{array}$ & $\begin{array}{l}3 \\
(9)\end{array}$ & $\begin{array}{l}5 \\
(7)\end{array}$ & $\begin{array}{l}2 \\
(6)\end{array}$ & $\begin{array}{c}4 \\
(13)\end{array}$ & $\begin{array}{c}1 \\
(2)\end{array}$ & 0 & $\begin{array}{l}22 \\
(5)\end{array}$ \\
\hline Other & $\begin{array}{c}4 \\
(10)\end{array}$ & $\begin{array}{c}5 \\
(11)\end{array}$ & $\begin{array}{c}9 \\
(21)\end{array}$ & $\begin{array}{c}4 \\
(13)\end{array}$ & $\begin{array}{l}1 \\
\text { (7) }\end{array}$ & $\begin{array}{l}1 \\
(8)\end{array}$ & & $\begin{array}{l}4 \\
(6)\end{array}$ & 0 & $\begin{array}{l}2 \\
(7)\end{array}$ & $\begin{array}{c}7 \\
(14)\end{array}$ & $\begin{array}{c}5 \\
(10)\end{array}$ & $\begin{array}{l}42 \\
(9)\end{array}$ \\
\hline Annual case total & 41 & 46 & 43 & 30 & 14 & 12 & 34 & 68 & 32 & 30 & 50 & 53 & 453 \\
\hline
\end{tabular}

Source: Hull City Archives, Hull Magistrates' Court Minute Books, DPM/I/76-83, 85-91, 93-4 96-102

a January-June and December only

$\mathrm{b}$ As a percentage of annual total 
to the fisherlads and to adult seamen prosecuted under the Merchant Shipping Act, which had comparable if not more severe sentences for deserters. Once again the numbers are striking. First, the sheer number of fishing apprentices cases is always larger, despite the fact that their representation in the maritime labor force was vastly smaller. Second, the percentage of prison sentences shows a clear imbalance. At an 82 per cent average rate of incarceration the fishing apprentices were fully twice as likely to be sent to prison as seamen for similar offences, such as disobeying orders or absconding.

Table 6 shows the distribution of sentences received by fisherlads. With the most common sentences being twenty-one, thirty, and seventy days in prison with hard labor, convictions were highly punitive. Interestingly, notations in the minute books indicate that around 20 to 30 per cent of these fisherlads were released to their masters prior to the completion of their sentences, and during one hearing Travis complained that " $[t]$ he only fault he had with some masters was that they were too anxious to take their boys out of prison before the expiration of their punishment". ${ }^{75}$

The data suggest that through both the apprenticeship and criminal justice systems smackowners found the means of controlling a portion of their labor supply that could not be maintained through a free labor market. On the one hand, they needed a supply of inexpensive labor to be able to insure that their net return from each voyage allowed them to work off mortgage payments and expenses and make a profit. On the other hand, this labor pool was young, often bound against their will, and became more valuable as a source of profit the greater their experience at sea. Therefore smack-owners were reluctant to part with apprentices, and indeed the records show very few such annulments of indentures.

The answer was to use the criminal justice system both as a means of threat and coercion - a disciplinary tool that could be used repeatedly and reliably against obstreperous apprentices - and also as a holding pen for this labor supply. Long sentences insured that apprentices could not flee in between voyages. The extent to which smack-owners were granted the early release of their charges also indicates that the punishment itself was secondary to securing access to this labor supply.

In Travis and the borough court the smack-owners found sympathetic ears. As Conley argues, the actions and pronouncements of the court need not be interpreted as an example of naked class interest. Rather, seen through the linked lens of bourgeois order and respectability, the waywardness of the fisherlads represented a serious problem, particularly given their often pauper origins. The concern of smack-owners was expressed by Alfred Ansell in I869 at a meeting of the South Myton Reform Association - the biggest borough ward and the one with the 
Table 6. Prison sentences of convicted fishing apprentices (in days), I864-1875

\begin{tabular}{|c|c|c|c|c|c|c|c|c|c|c|c|c|}
\hline Sentence length & 1864 & 1865 & 1866 & 1867 & $1868^{a}$ & $1869^{a}$ & 1870 & 1871 & 1872 & 1873 & 1874 & 1875 \\
\hline $1-14$ & 11 & 31 & 14 & 4 & 5 & 1 & 6 & 5 & 2 & 7 & 6 & 10 \\
\hline $15-28$ & 14 & 25 & 32 & 22 & 22 & 6 & 14 & 12 & 17 & 31 & 35 & 41 \\
\hline $29-42$ & 8 & 9 & 23 & 37 & 15 & 17 & 31 & 38 & 46 & 43 & 49 & 63 \\
\hline $45-56$ & 0 & 4 & 3 & 4 & 1 & 1 & 4 & 5 & 3 & 3 & 8 & 14 \\
\hline $57-70$ & 9 & 23 & 23 & 23 & 15 & 13 & 24 & 21 & 29 & 28 & 26 & 31 \\
\hline Total & 42 & 92 & 95 & 90 & 58 & 38 & 79 & 81 & 97 & 112 & 124 & 159 \\
\hline
\end{tabular}

Source: Hull City Archives, Hull Magistrates' Court Minute Books, DPM/I/76-83, 85-91, 3-96-102

a January-June and December only 
largest concentration of smack-owners - in which he noted that steps had been taken to "improve the moral condition of the fishermen", and that the decline in the number of apprentice prosecutions from the previous year was a signal of their success. ${ }^{76}$

These actions were best exemplified by the room and school inaugurated for fishing apprentices at the Fish Street Chapel in the latter I860s. Characteristic of the times, the school provided regular Sunday Bible study classes, and by I 875 it claimed to have had I, 300 to I, 400 participants in them. Its reading room was open several nights a week, it made available savings accounts, and had an annual tea that drew between 100 and 200 fisherlads each April. Some of the largest smack-owners were involved in its governance, including Ansell, its secretary, who was also one of the main prosecutors of apprentices during this period. The school mirrored the larger concern of smack-owners and town elite for fishermen in general, which was reflected in their founding and maintenance of a Fishermen's Institute. The Institute was similar to the mechanics' institutes of the times, and sought to provide spiritual and intellectual outreach and sustenance to the growing legions of adult fishermen. ${ }^{77}$

Less systematic evidence from the nearby port of Grimsby, where the trade grew even more rapidly (eventually dwarfing Hull) suggests a similar pattern. Fleming's i 873 report into the status of apprentices in that town records that for the previous administrative year (I May i 872-30 April I873) there were $25 \mathrm{I}$ total cases involving fishing apprentices, 208 for absconding, 33 for disobeying orders, and the remainder for other offences. ${ }^{78}$ Of these, io per cent of the prosecutions represented repeat offences, 62 per cent of the hearings resulted in convictions, a somewhat lower rate than in Hull, and the most common sentences were of two and three weeks' imprisonment. In Grimsby magistrates relied on the Merchant Shipping Act for prosecution, which the Hull magistrates turned to after the repeal of the Master and Servant Act in I875. It is not clear why the latter justices chose a different legal foundation, nor exactly why, after the reformation of the Merchant Shipping Act in I 880, they interpreted it sections in a way that stopped them for using it for further prosecutions while their Grimsby counterparts continued to do so. ${ }^{79}$

\footnotetext{
76. Hull and Eastern Counties Herald, 25 November 1869.

77. Hull and Eastern Counties Herald, 3 March, I s April I869, 3 February I870, I 3 April I 871, I8 April I872, 24 April I873, 9 April I874, 8 April I875.

78. Fleming claimed that "a considerable proportion of the fishing apprentices contract venereal disease and it was stated to me that lads purposely committed offences when so diseased in order that they might receive medical attendance in Lincoln County Prison"; PRO MH/32/99, Fleming, "Treatment of Pauper Apprentices", fo. 42.

79. PRO MH/32/99, Fleming "Treatment of Pauper Apprentices", fo. 40-4I; see also Boswell, Sea Fishing Apprentices, pp. 79-83; Horn "Pauper Apprenticeship"; Robinson, A History of the Yorkshire Coast Fishing Industry; "Report of a Committee", BPP I 882 XVII, p. 64. My thanks to Martin Wilcox for clarifying the legal bases of prosecution in Hull and Grimsby.
} 
It is apparent from the data that employers in the trawling industry were the only Hull capitalists to employ the law systematically as a means of labor control. As Table 7 overleaf shows, nineteen of the top twenty prosecutors were smack-owners. ${ }^{80}$

The paucity of all other master and servant prosecutions during this period, and the relatively low percentage of prosecutions of seamen under the Merchant Shipping Act give credence to the argument that the practice was employed by smack-owners, given their control of the labor supply, the labor process, and their requirements for cheap labor to stay afloat. As Fleming himself noted in his report on the Grimsby apprentices, "For its ensuing continuance and development, it is absolutely necessary that the lads should be obtained as apprentices to the trade."8I Many smackowners were heavily mortgaged. They faced a growing but also increasingly competitive trade, not only among their peers in Hull, but also from the trawlers of nearby Grimsby, Whitby, Scarborough, and other ports in the south as well. ${ }^{82}$ Moreover, it is probable that an increasing proportion of their labor force was also the least enthusiastic, i.e. Poor Law Union boys who were bound to relinquish their home parishes of a burden. A number of these apprentices were shipped considerable distances, including from London parishes. As Boswell suggests, many were physically unprepared for the rigors of the sea. ${ }^{83}$

Legal action became a lynchpin to keep this system of exploitation in motion. The Master and Servant Act, coupled with apprenticeship binding, insured that smack-owners had unlimited power over this portion of their labor supply. The borough court and police provided a ready enforcement mechanism for this power. Drawing on the authority of the criminal justice system, smack-owners were not only able to create a potent disciplinary system, they were also able to securely house recalcitrant labor at the expense of the borough until needed for use. This was certainly not a system of slavery, but in its darker dimensions there are some disconcerting parallels.

By I 880 the industry in Hull alone employed some I,200 apprentices, and there was probably a larger number in Grimsby. ${ }^{84}$ There were by then 420 smacks with some $£ 500,000$ invested in Hull's trade. ${ }^{85}$ Changes in the Merchant Shipping Act and the passage of the Payment of Wages Act in I 880 led to the abandonment of apprentice labor in Hull, though in

80. J.W. Beeton was a basketmaker who had repeated run-ins with several of his apprentices in the first half of the period.

8r. PRO MH/32/99, Fleming, "Treatment of Pauper Apprentices", fo., 46.

82. This supports Hay's claim that prosecutions rose with increased competition in an industry

"Master and Servant in England", p. 244.

83. Boswell, Sea Fishing Apprentices, p. 58.

84. Ansell, On Trawling, p. 23; BPP i 882, XVII, p. 4I.

85. Bellamy, The Trade and Shipping, p. 49. 
Table 7. Most frequent prosecutors of apprentices by number of convictions, I $864-1875$

\begin{tabular}{llcc}
\hline Name & Trade & $\begin{array}{c}\text { Convicted } \\
\text { apprentices }\end{array}$ & $\begin{array}{c}\text { Number of } \\
\text { trawlers }\end{array}$ \\
\hline Beeton, J.W. & Basket-making & 38 & - \\
Halfyard, Thomas & Trawling & 31 & n.a. \\
Rogers, George & Trawling & 25 & n.a \\
Rouse, John & Trawling & 24 & 5 \\
Loram, Richard & Trawling & 22 & 6 \\
Shepherd, H.C.W. & Trawling & 22 & n.a. \\
Bates, Peter & Trawling & 21 & n.a. \\
Anderson, George & Trawling & 20 & 2 \\
Evans, James & Trawling & 19 & 7 \\
Exon, William & Trawling & 19 & n.a. \\
Harding, James & Trawling & 19 & 5 \\
Ansell, Alfred & Trawling & 17 & 11 \\
Drew, Walter & Trawling & 17 & n.a. \\
Maddock, Henry & Trawling & 17 & 4 \\
Apter, Thomas & Trawling & 16 & n.a. \\
Pollard, J.C. & Trawling & 16 & n.a. \\
Vinton, Charles & Trawling & 16 & n.a \\
Palmer, David & Trawling & 15 & n.a. \\
Webb, John & Trawling & 15 & 3 \\
Blanchard, Henry & Trawling & 13 & 5 \\
\hline
\end{tabular}

Grimsby and perhaps other fishing ports the practices waned more slowly. This was in part because of variations in the local labor supply. As an I 894 Parliamentary report noted, "if there had been at Grimsby the same supply of weekly hands as there is at Hull and Lowestoft it is probable that the apprentice system would have died out as it has done in other ports". ${ }^{86}$ Perhaps this is why the Hull magistrates interpreted a critical section in the Merchant Shipping Act regarding willful disobedience as applying to onboard behavior only, while their Grimsby counterparts understood it to mean desertion as well. ${ }^{87}$ Such was the nature of the local state. As a result apprentices in Grimsby continued to abscond in substantial numbers, and many fled to Hull where their labor was finally and fully freely contractual. ${ }^{88}$ As the beam size for the trawl grew, increasing the efficiency of the labor, casual labor replaced apprentices in most other ports. Youth labor became less vital and smack-owners relied on a larger transient labor pool. More importantly, by the I 88 os the Yorkshire fleets were beginning

86. Chance, Children Under the Poor Law, p. $28 \mathrm{I}$.

87. "Report of a Committee", BPP i 882, XVII, pp. xii, 64.

88. An 1894 Parliamentary report noted that one-third of all Grimsby apprentices absconded between I88I-1893; Chance, Children Under the Poor Law, p. 279. 
to lose a competitive battle with a burgeoning Scottish industry, and the trade experienced a slow decline. ${ }^{89}$

\section{CONCLUSION}

Reflecting on the industry, Robinson remarks, "It remains ironic that a trade which benefited so much from laissez-faire on the high seas should have relied so heavily and for so long on such a tied and ragged labor force." 90 However, as the role of unfree labor in England's economic development during the eighteenth and nineteenth centuries becomes more fully exposed this reliance perhaps will seem less ironic. For growing industries with an increasing need for workers to fill unskilled, lowpaying, and undesirable jobs, urban parishes were all too willing to relieve themselves of unwanted pauper charges in the form of apprenticed labor. Indeed, even after considerable unwanted public and parliamentary scrutiny in I 882 after two publicized brutal deaths of fisherlads at the hands of their skippers, the trawling industry continued to rely heavily on apprentice labor as a mainstay. ${ }^{9 \mathrm{I}}$

As importantly, the Hull case provides a glimpse at the ways in which master and servant law and local courts provided a venue for the exercise of labor discipline and control. Elsewhere I have detailed the ways in which pottery manufacturers drew on these laws as important means of keeping their skilled male workers in line in the absence of alternatives. In that work I show that many of the largest and most prominent employers in the pottery industry in Hanley, Staffordshire relied on master and servant law to keep their skilled male workers in line..$^{92}$ Even though the production process employed a high division of labor, it still depended on manual skill and was carried out in workshops without much direct supervision. Capitalists could not easily introduce the discipline of steam-powered machinery, and lacking other alternatives, even the large pottery

89. Robinson, A History of the Yorkshire Coast, pp. 83-99.

90. Idem, Trawling, p. 65 .

91. Rule, "Smackmen of the North Sea", p. 395. For details of the parliamentary investigation, see "Report of a Committee", BPP I 882 XVII, (3432). Horn notes that between I880-I909, 5, I76 boys signed indentures for Grimsby masters, about one-half of whom came from about I70 Poor Law Unions, though the numbers were declining in the I 890 . As many as one-quarter of these fisherlads were imprisoned during this period and the 1883 revision of the Merchant Shipping Act actually provided greater powers for the local marine superintendent to issue warrants for absconding apprentices; Horn, "Pauper Apprenticeship", pp. I77, i 84, i87.

92. Marc W. Steinberg, "Capitalist Development, the Labor Process and the Law: The Case of the Victorian English Pottery Industry”, American Journal of Sociology, ro9 (2003), pp. 445-495, and idem, "Capitalist Law, Relations of Production and Exploitation, and Structured Possibilities for Contention, or Using Three Tillys to Make One Argument”, in Maria Kousis and Charles Tilly (eds) Economic and Political Contention in Comparative Perspective (Boulder, CO, 2005), pp. 33-47. 
manufacturers looked to the magistrates' court as an effective means of discipline. 93

The annual parliamentary reports from I 858 to the repeal of the laws in I 875 suggest that these two trades were hardly unique. Moreover, the tenacity with which employers from industries such as iron-making, coal and iron ore mining, the building trades, and others opposed the abolition of the criminal provisions of master and servant laws suggests their utility for a variety of capitalists. ${ }^{94}$ Further research on these industries and in earlier decades of the nineteenth century (especially prior to the era of parliamentary reports for which we lack data on convictions) are necessary to establish the extent of and reasons for its use.

The Hull case suggests that Daphne Simon's depiction of master and servant law as being a waning vestige of a bygone era is somewhat off the mark. ${ }^{95}$ Hull trawling masters turned to apprentice labor and the discipline of the law precisely when she argues it was in its last throes. And while this study does affirm her assertion that master and servant law was a coercive tool of small masters, other recent work, including my own study of the Hanley earthenware manufacturers, suggests that this claim too should be re-examined. ${ }^{96}$

As we have seen, fishing trawler owners were not major players in Hull politics and most cases were administered by a stipendiary magistrate. That high rates of successful prosecution could occur in front of benches of quite different composition raises questions about the specific institutional development of local legal cultures in areas

93. As Hay argues, master and servant law was particularly useful in maintaining discipline among skilled workers over whom employers otherwise had little control; Hay, "England, I 562-I875", p. I0I. More broadly, Deakin and Wilkinson assert that, "the significance of the master and servant legislation lay in providing employers with a mechanism for imposing discipline on workers who otherwise had only a loose organizational connection to the firm, and who would often be in a position to take advantage of labour shortages to push up wages. [...]. The historical evidence suggests that the disciplinary mechanism of the Acts was widely used as an instrument of economic regulation during a period when modern managerial techniques had yet to develop"; Simon Deakin and Frank Wilkinson, The Law of the Labour Market: Industrialization, Employment and Legal Evolution (Oxford, 2005), pp. 70-71.

94. For details of the contention concerning revision in I 867 and ultimate repeal of master and servant laws with the passing of the Employers' and Workmen's Act of i 875, see Curthoys, Government, Labour and the Law. For opposition to the reform of the law among these industries, see Report from the Select Committee on Master and Servant, I866, XIII (449), pp. $55-58,67-68$, I06-I I 4, I 20-I22, I 24-I28, and the returns to the Royal Commission on Trade Unions questionnaire, "Eleventh and Final Report of the Royal Commissioners Appointed to Inquire into the Organization and Rules of Trade Unions and Their Associations", vol. 2, XXXI I 868-I869 [4I23-I], App. E, pp. 86-I42. Hay notes that there was likely an expansion of the use of master and servant laws after I 800 and prior the collection of statistics in I858; Hay, "England, I $562-1875$ ”, p. I0I.

95. Simon, "Master and Servant", p. 195. As Hay argues, the penal character of the law actually intensifies throughout most of the nineteenth century; Hay, "England, I 562-1875", pp. 106, I09. 96. Simon, "Master and Servant", p. 192. 
where employers turn most frequently to the law. Pottery manufacturers were heavily represented on the borough court and had a very cordial relationship with the Potteries stipendiary magistrate, and workers had for years raised complaints about the partiality of justice in the town. ${ }^{97}$ Certainly, previous work by Woods and others alerts us to an institutional culture of prosecution across many towns and industries in the Black Country..$^{8}$ These variations suggest that we need additional local studies to develop a better understanding of how these legal cultures germinated, and how employers institutionalized a turn to the law in their repertoire of labor discipline.

Beyond these standout areas for prosecution, however, we need more investigation into how master and servant and other law colored the web of relations of authority and control in the workplace. As the counsel for the Mining Association of Great Britain readily acknowledged, the mine owners he represented used the law "in terrorem", with its threat as effective a disciplinary tool as an actual prosecution. Similarly, the manager of the enormous Dowlais Iron Works in Wales, which employed I I,000 in all of its operations, noted that he used the law sparingly, but that, "I see that taking a man down to Merthyr [Tyfdil] and fining him, and in default of his paying the fine sending him to prison, restrains scores and scores of men from committing the same act probably for a month or so." 99 Hay and Craven suggest, indeed, that in England the vast majority of conflicts were settled "in the shadow of the law" without ever reaching the bench. ${ }^{100}$

Finally, Hull and other cases suggest a need to focus more on the role of the courts and the power of the local state in nineteenth-century economic development. As the nineteenth century progressed more local magistrates were drawn from the ranks of manufacturers, middle-class professionals, and tradesmen sympathetic to the concerns of the first group. With the passing of the Municipal Corporations Act of 1835 the consolidation of bourgeois control quickened in pace. Heightened powers of local courts and their increasingly reliability for employers led to increasing ire and

97. Steinberg, "Capitalist Development", pp. 468-47I.

98. Woods, "The Operation of the Master and Servants Act in the Black Country"; Philips, "The Black Country Magistracy". In addition to the towns discussed by these historians, my provisional work with the magistrates' court entry books for Willenhall, Staffordshire shows that lock manufacturers in that town relied heavily on master and servant prosecutions, even for some months after the repeal of the law in mid-August of 1875 ; Walsall Local History Centre, Willenhall Magistrates' Court Entry Books, 254-I-8, May i 873-January i 876.

99. First Report of the Commissioners Appointed to Inquire into the Working of the Master and Servant Act, I867, and The Criminal Law Amendment Act, 34 \& 35 Vict. Cap. 32, PP I 874 [c. I094] XXIV, pp. I47, I 5 . See also Franks, “'Let But One of Them Come Before Me, and I'll Commit Him'”, p. 87.

ıо०. Hay and Craven, "Introduction", p. 43. 
calls for reform among working-class leaders. ${ }^{\text {I0I }}$ Even as Britain projected its imperial power around the globe with the aid of a growing state bureaucracy in the capital, it was the local court that was the touchstone of power for ordinary people and their worlds of work. Further research need to chart the ways in which capitalists in industries and regions around the nation relied on the power of this local state even as they trumpeted the virtues of laissez-faire.

Iог. Hay "England, I 562-1875", p. I05. This has been well documented in the case of the Black Country. See Philips, "The Black Country Magistracy”; Woods, "The Operation of the Master and Servants Act in the Black Country"; Franks, "Let But One of Them Come Before Me, and I'll Commit Him'”. 